\title{
A Mixed-Method Research on Recreation Space for Youth in Malaysia
}

\author{
Dasimah Omar, Kamarul Ariff Omar, Zaharah Mohd Yusoff, Fazzami Othman \\ Faculty of Architecture Planning and Surveying, \\ Universiti Teknologi MARA, Universiti Teknologi Mara (UiTM), \\ 40450 Shah Alam, Selangor, Malaysia
}

Dasimah629@uitm.edu.my, kamarulariff@uitm.edu.my,zmy1208@uitm.edu.my, fazzamiothman@gmail.com Tel: +60139144491

\begin{abstract}
This research applied a mixed-methods analysis of the recreation space for youth in Malaysian urban and rural areas applying both the qualitative and quantitative approach. For qualitative research, four (4) focus group discussions (FGD) with 24 youth and 22 stakeholders have conducted while for quantitative research, a total of 800 youth selected as respondents. The quantitative research questionnaire based on the outcome of the FGD. The results found that the provision of recreational space in urban and rural areas including location, adequacy ratio, current condition, proximity, accessibility and level of maintenance required to reviewed for improvement.
\end{abstract}

Keywords: Youth, Space, Qualitative, Quantitative

eISSN: 2398-4287 @ 2020. The Authors. Published for AMER ABRA cE-Bs by e-International Publishing House, Ltd., UK. This is an open access article under the CC BYNC-ND license (http://creativecommons.org/licenses/by-nc-nd/4.0). Peer-review under responsibility of AMER (Association of Malaysian Environment-Behaviour Researchers), ABRA (Association of Behavioural Researchers on Asians) and cE-Bs (Centre for Environment-Behaviour Studies), Faculty of Architecture, Planning \& Surveying, Universiti Teknologi MARA, Malaysia. DOI: https://doi.org/10.21834/ebpj.v5iSI2.2518.

\begin{abstract}
1.0 Introduction
With rapid development and urbanisation in Malaysia, recreation spaces become necessary components in urban, rural areas. Recreation space allows people regardless of unique background to use the space, to enjoy nature and serve as gathering places for social activities and events. The research aimed to conduct a mixed-method analysis of the recreation space for youth in Malaysian urban and rural areas, applying both the qualitative and quantitative approach. Provided in their neighbourhood areas. The youth referred to as a person between the ages of 15 to 25 years old. At this age, most of them spend much of their lives in education settings, whether in secondary school, university or college. During their leisure time, they spend more time on outdoor activities with friends who are staying in the neighbourhood.
\end{abstract}

\subsection{Literature Review}

This research focuses on the physical aspects of recreational space. It refers to the recreational space provision which includes adequacy ratio, level of satisfaction with the use of recreational space, the accessibility and level of maintenance of existing recreational space. The sound social interaction needs an appropriate physical space including criteria of design, activities, access and linkage, administration and maintenance, place attachment and users' characteristics. The previous study also comprises a health perspective with measures of physical activity of open spaces (Salih, S.A., Ismail, S., 2018). Ward Thompson, C. (2013) argued that good quality of

eISSN: 2398-4287 ( 2020. The Authors. Published for AMER ABRA cE-Bs by e-International Publishing House, Ltd., UK. This is an open access article under the CC BYNC-ND license (http://creativecommons.org/licenses/by-nc-nd/4.0/). Peer-review under responsibility of AMER (Association of Malaysian Environment-Behaviour Researchers), ABRA (Association of Behavioural Researchers on Asians) and cE-Bs (Centre for Environment-Behaviour Studies), Faculty of Architecture, Planning \& Surveying, Universiti Teknologi MARA, Malaysia.

DOI: https://doi.org/10.21834/ebpj.v5iSI2.2518. 
recreation space depends on the perception and satisfaction of human needs. Here, information about users' perceptions and needs would be beneficial for the further improvement of the space. Thus, the users' preferences and perceptions may help understand the needs of users for the further improvement of the space (Yeshpanova, D., Narbekova, G., Biyekenova, N., Kuchinskaya, J. \& Mukanova, O. (2014).

Youth mental health is also inadequately managed, and traditional psychosocial interventions fail to reduce the high rate of aggression, anxiety, depression, and poor emotional regulation (Angel Dzhambov, Terry Hartig, lana Markevych, Boris Tilov, Donka Dimitrova, 2018). Alessandro Rigolon, Matthew Browning, Viniece Jennings (2018) stated that neighbourhood-level inequities in park provision might scale up to inequities across cities. Their study contributes to environmental justice theory and advocacy by demonstrating the importance of scaling up analyses of park provision to cross-city comparisons. Implications for urban and rural planning, public policy, and grant-making should be discussing. Public space is a necessary element of a city that can influence the quality of the local environment, physical, ecological roles and also contribute to the mental and psychological health of human beings. An outdoor gym is an environmental infrastructure built in a public open space to promote structured physical activity, seen as an essential strategy to realise public health agendas promoting habitual physical activity (Janet Lok Chun Lee and Tommy Lee Ting Lo, 2018). The continued involvement in green space health research expected to engage policy-makers in evidence-based city planning (Angel Dzhambov, Terry Hartig, lana Markevych, Boris Tilov, Donka Dimitrova, 2018). Thomas C. Ricketts, (1998), defined rural people as those who live in places with small populations or unincorporated areas with a population density less than 1,000 per square mile. The meaning of urban as comprising all territory, population, and housing units in urbanised areas and places of 2,500 or more persons outside urbanised areas.

\subsection{Method}

The mixed-methods were applied to collect the data: focus group discussions for the qualitative and interviewing respondents using questionnaires for the quantitative data. This research began with the qualitative data. The first FGD focused on the urban area of Lembah Pantai Kuala Lumpur with 11 stakeholders and followed by the second FGD with the 12urban youth. The third FGD was held with 11stakeholders and the fourth FGD with 12 youth from Kota Samarahan as the rural area. The stakeholders included professional people such as police officers, health officers, town planners, parents, Malaysian Youth Council Committee and residential committee members. They were selected randomly according to several criteria representing gender, age 15 to 25 years old, and the races (Malay, Chinese, Indian). The youth were students, employed and unemployed, and some are married. These FGDs held at different venues. The first FGD with urban youth was at community hall between 3-5 pm. The time was appropriate as most of them were in schools in the morning. The second FGD with stakeholders was held at $10 \mathrm{am}-12 \mathrm{pm}$ at the Armada Hotel in Petaling Jaya, which is accessible to all participants. The third and fourth FGDs held in Universiti Teknologi MARA, Kota Samarahan as a rural case study area.

The morning session with the stakeholders while the afternoon with the youth. The next stage was a quantitative data collection. A set of questionnaires has developed through the variables and issues from the FGD sessions. This questionnaire contains 2 (two) parts which are Part A (Respondents' background) and Part B on their satisfaction level on recreation space provision. A total of 400 questionnaires distributed randomly. The study area divided into two categories, rural and urban areas-Table 1 shows 540 respondents living in urban areas in Lembah Pantai and Kota Kinabalu. For rural areas, respondents are from FELDA Jengka and Kota Samarahan with a total of 260 respondents.

Table 1: Number of Respondents by Areas

\begin{tabular}{|c|c|c|}
\hline \multicolumn{3}{|l|}{ Housing Areas } \\
\hline Areas & Frequency & Percentage \\
\hline Lembah Pantai (urban) & 400 & 50.0 \\
\hline Kota Kinabalu (urban) & 140 & 17.3 \\
\hline Kota Samarahan (rural) & 130 & 16.3 \\
\hline FELDA Jengka (rural) & 130 & 16.5 \\
\hline Total & 800 & 100.0 \\
\hline
\end{tabular}

\subsection{Result and Discussion}

There are eight types of recreational spaces listed, including futsal court, badminton court, basketball court, tennis court, soccer field, children's playground, gymnasium and jogging track. Based on space thematic analysis for qualitative data showed the spaces are not only for recreation activities, but also used as an assembly point, meeting place, and social interaction space for the local community. The recreation spaces are limited in number and not adequately maintained. The majority of respondents felt very disappointed upon the existing space. The youth participants frequently quoted that they were frustrated and unpleasant upon their surrounding living 
environment. Most of them prefer to go to other places outside their neighbourhood. Majority of FGD respondents agreed that there is insufficient recreation space for youth both in urban and rural areas. Some of the respondents quoted that youth should not be giving particular space in the neighbourhood.

Table 2: Type and Availability of Recreation Space

\begin{tabular}{|c|c|c|c|c|c|c|c|}
\hline \multirow{3}{*}{\multicolumn{2}{|c|}{ Types of Recreation Facilities }} & \multicolumn{6}{|c|}{ Availability of the Recreation Facilities Provided In Youth's Area } \\
\hline & & \multicolumn{3}{|l|}{ Yes } & \multicolumn{3}{|l|}{ No } \\
\hline & & \multirow{2}{*}{$\begin{array}{l}\text { Urban } \\
518\end{array}$} & \multirow{2}{*}{$\begin{array}{l}\text { Rural } \\
148\end{array}$} & \multirow{2}{*}{$\begin{array}{l}\text { Total } \\
666\end{array}$} & \multirow{2}{*}{$\begin{array}{l}\text { Urban } \\
61\end{array}$} & \multirow{2}{*}{$\begin{array}{l}\text { Rural } \\
73\end{array}$} & Total \\
\hline 1. & Futsal Court & & & & & & 134 \\
\hline 2. & Badminton Court & 455 & 176 & 631 & 123 & 45 & 168 \\
\hline 3. & Basketball Court & 47 & 66 & 113 & 530 & 155 & 685 \\
\hline 4. & Tennis Court & 21 & 5 & 26 & 557 & 216 & 773 \\
\hline 5. & Football Field & 535 & 197 & 732 & 42 & 23 & 65 \\
\hline 6. & Playground & 487 & 142 & 629 & 89 & 79 & 168 \\
\hline 7. & Gymnasium & 51 & 49 & 100 & 527 & 172 & 699 \\
\hline 8. & Jogging Track & 414 & 36 & 450 & 162 & 185 & 347 \\
\hline
\end{tabular}

The quantitative data analysis showed that there are recreational spaces in their neighbourhood areas. Badminton court and futsal court are available more in urban areas than in rural areas. Due to the lack of more significant land for the football field and the lifestyle of youths living in urban areas. The urban youth prefer night time to carry out recreational activities. This type of recreational space requires the use of indoor space in a building, and the activities can be at any time and as it not exposed to the weather. Table 2 shows the availability of recreation space stated by respondents from both urban and rural areas. For the football field, gets the highest score in the provision of recreational space. A total of 732 respondents consisting of 535 youth from both urban areas and 197 respondents living in rural areas stated that there is a football field in their neighbourhood. Generally, football fields provided in both urban and rural areas due to the game being the most popular sports. In Malaysia, football and badminton are top-rated games compared to other sports. Only 21 respondents in the urban area said there are tennis courts provided, and the balance of 557 respondents stated no tennis courts provided.

Concerning the youth involvement toward the recreational space in urban and rural areas, it found that the majority of the respondents use futsal courts with 438 youth, 405 of respondents selected the soccer ball, 402 respondents preferred the playground, and 359 respondents selected the badminton court. Some respondents were aware of the availability of recreational space but did not use it-table 3 reviews the youth satisfaction level towards the recreational space provided. Playground achieved the highest of 3.66 mean and futsal court in the second list with 3.62 means. Majority of respondents chose level 3, which refers to Less Satisfied. Tennis court achieved a lower level of satisfaction with 3.30 mean as respondents were less satisfied. Referring to the distance factor analysis, the badminton court is where the youth use for gathering and playing badminton achieved the highest level of 3.86mean with the majority of respondents being almost satisfied. The futsal court is the second higher level with 3.85 means. Recreational space for tennis courts is the lowest with 3.17 mean.

Table 3: Respondents 'Satisfaction Mean Level

\begin{tabular}{|c|c|c|c|c|c|c|c|c|c|c|}
\hline \multirow[b]{2}{*}{$\begin{array}{l}\text { Recreation } \\
\text { Facilities } \\
\text { Provided in } \\
\text { Rural And } \\
\text { Urban Areas }\end{array}$} & \multicolumn{2}{|c|}{ Sufficient } & \multicolumn{2}{|c|}{ Satisfaction } & \multicolumn{2}{|c|}{ Distance } & \multicolumn{2}{|c|}{ Accessibility } & \multicolumn{2}{|c|}{ Maintenance } \\
\hline & $\begin{array}{c}\text { Total } \\
\text { Respondents }\end{array}$ & Mean & $\begin{array}{c}\text { Total } \\
\text { Respondents }\end{array}$ & Mean & $\begin{array}{c}\text { Total } \\
\text { Respondents }\end{array}$ & Mean & $\begin{array}{c}\text { Total } \\
\text { Respondents }\end{array}$ & Mean & $\begin{array}{c}\text { Total } \\
\text { Respondents }\end{array}$ & Mean \\
\hline 1. Futsal Court & 656 & 3.62 & 656 & 3.57 & 657 & 3.85 & 654 & 3.85 & 655 & 3.63 \\
\hline $\begin{array}{l}\text { 2. Badminton } \\
\text { Court }\end{array}$ & 630 & 3.56 & 629 & 3.58 & 629 & 3.86 & 627 & 3.88 & 627 & 3.69 \\
\hline 3. Basketball & 116 & 3.34 & 116 & 3.31 & 116 & 3.46 & 116 & 3.39 & 116 & 3.39 \\
\hline 4. Tennis Court & 24 & 3.33 & 23 & 3.30 & 23 & 3.17 & 23 & 3.30 & 23 & 2.96 \\
\hline $\begin{array}{l}\text { 5. Football } \\
\text { Field }\end{array}$ & 715 & 3.31 & 715 & 3.46 & 715 & 3.60 & 712 & 3.71 & 698 & 3.47 \\
\hline 6. Playground & 635 & 3.66 & 635 & 3.62 & 635 & 3.89 & 634 & 3.86 & 633 & 3.68 \\
\hline 7. Gymnasium & 99 & 3.59 & 99 & 3.43 & 99 & 3.54 & 98 & 3.51 & 99 & 3.39 \\
\hline $\begin{array}{l}\text { 8. Jogging } \\
\text { Track }\end{array}$ & 478 & 3.47 & 480 & 3.62 & 480 & 3.68 & 480 & 3.68 & 479 & 3.60 \\
\hline
\end{tabular}

For the location of recreation space, the respondents chose the third level of satisfaction with their residential proximity to recreational space in their neighbourhoods within their accessibility and ease of the visit. They prefer to walk to the recreational space. The majority selected the third level satisfaction towards the condition and maintenance factor. The recreational space provided in rural and urban 
areas is not significantly different in terms of sufficiency, satisfaction, accessibility and maintenance level. The urban respondents in Lembah Pantai were living in flats with limited space. They were not satisfied with the level of maintenance of the space provided. Accessibility is via public transportation. Factors of distance and accessibility were faced by youth from rural areas Lifestyle factors of urban youth affected the use of recreational space provided. Exposure to sophisticated technology caused them to spend more time in cyber cafes, surfing the internet and using different types of gadgets.

\subsection{Conclusion}

The recreational space for youth needs improvement and upgrading, especially for urban areas including adequacy ratio, proximity, accessibility and level of maintenance. Involvement of the local authorities and other related agencies in providing adequate recreational space are appreciated.

\section{Acknowledgement}

This research paper is made possible by the Longterm Research Grant Scheme (LRGS 2014-0006-106-42), Universiti Pendidikan Sultan Idris Perak associated with Universiti Teknologi MARA and Universiti Putra Malaysia.

\section{References}

Alessandro Rigolon, Matthew Browning, Viniece Jennings, (2018), Inequities in the quality of urban park systems: An environmental justice investigation of cities in the United States, Landscape and Urban Planning, Vol. 178, Oct. 2018, (156-169)

Angel Dzhambov, Terry Hartig, lana Markevych, Boris Tilov, Donka Dimitrova, (2018), Urban residential green space and mental health in youth: Different approaches to testing multiple pathways yield different conclusions, Environmental Research Vol. 160, Jan. 2018, (47-59)

Janet Lok Chun Lee and Tommy Lee Ting Lo, (2018), Understanding Outdoor Gyms in Public Open Spaces: A Systematic Review and Integrative Synthesis of Qualitative and Quantitative Evidence, Int. J. Environ. Res. Public Health, 15(4)

Salih, S.A., Ismail, S., (2018), Criteria for Public Open Space Enhancement to Achieve Social Interaction: a Review Paper, IOP Conference Series: Materials Science and Engineering291(1)

Thomas C. Ricketts, PhD, (1998), Definitions of Rural: A Handbook for Health Policy Makers and Researchers, University of North Carolina

Ward Thompson, C. (2013). Activity, exercise and the planning and design of outdoor spaces. Journal of Environmental Psychology, 34, (79-96)

Yeshpanova, D., Narbekova, G., Biyekenova, N., Kuchinskaya, J. \& Mukanova, O. (2014). Social Activity of Youth in Social and Cultural Measurement. Procedia - Social and Behavioral Sciences, 140, (109-114) 